\title{
FAKTOR-FAKTOR YANG MEMENGARUHI PEMBELI ONLINE DI INDONESIA
}

\section{Factors Influencing Online Consumer in Indonesia}

\author{
Ribut Nurul Tri Wahyuni \& Sandra Logaritma \\ Sekolah Tinggi IImu Statistik, Jalan Otto Iskandardinata No.64C 1 4, RT.1/RW.4, Bidara Cina, \\ Kecamatan Jatinegara, Kota Jakarta Timur, DKI Jakarta, 13330, Indonesia \\ E-mail: rnurult@stis.ac.id
}

Naskah diterima: 17/09/2018; Naskah direvisi: 01/07/2019; Disetujui diterbitkan: 12/11/2019 Dipublikasikan online: 31/12/2019

\begin{abstract}
Abstrak
Saat ini, teknologi berkembang pesat di Indonesia. Salah satu bentuk pemanfaatan teknologi adalah perdagangan berbasis online (e-commerce). E-commerce dapat memberikan banyak manfaat jika dapat dilaksanakan dengan baik dan didukung oleh regulasi pemerintah. Perkembangan e-commerce sangat dipengaruhi oleh jumlah pelanggan, tetapi saat ini baru $3,18 \%$ penduduk Indonesia yang telah melakukan pembelian secara online. Penelitian ini membahas faktor-faktor yang dapat memengaruhi 'persentase pembeli online' di Indonesia dengan menggunakan data cross section, yaitu provinsi-provinsi di Indonesia tahun 2017. Metode yang digunakan adalah metode analisis jalur (path analysis) untuk melihat pengaruh langsung dan tidak langsung dari variabel persentase pengguna internet per jumlah penduduk, pendapatan per kapita, dan rata-rata lama sekolah terhadap persentase pembeli online. Hasilnya adalah persentase pengguna internet berpengaruh langsung terhadap persentase pembeli online. Sedangkan pendapatan per kapita dan rata-rata lama sekolah berpengaruh tidak langsung terhadap persentase pembeli online. Untuk mendukung peningkatan persentase pembeli online di Indonesia, pemerintah perlu meningkatkan anggaran untuk infrastruktur komunikasi, pendidikan, dan sumber daya manusia.
\end{abstract}

Kata Kunci: E-commerce, Pembeli Online, Metode Analisis Jalur

\begin{abstract}
Nowadays, technology grows rapidly in Indonesia. One of the technology utilization is online shopping (e-commerce). E-commerce can provide benefits if it is implemented properly and supported by government regulations. The development of e-commerce is strongly influenced by the number of customers, but the percentage of Indonesians buying online is only $3.18 \%$. This research discusses the influencing factors of online customers in Indonesia by using cross-section data (provinces in Indonesia in 2017). It uses the path analysis method to find the direct and indirect effect of the percentage of internet users per total population, income per capita, and educational attainment to the percentage of online consumers. The percentage of internet users has a direct effect on the percentage of online consumers. Income per capita and educational attainment have an indirect effect on the percentage of online consumers. To increase the percentage of online customers in Indonesia, the government needs to increase the budget on communication infrastructure, education, and human resources.
\end{abstract}

Keywords: E-commerce, Online Customer, Path Analysis

JEL Classification: C390, L810, M380

\section{PENDAHULUAN}

Sejak tahun 2011, negara-negara

di dunia telah memasuki industri 4.0

yang ditandai dengan meningkatnya interaksi antar manusia melalui teknologi. Jika suatu negara dapat memanfaatkannya dengan baik, perkembangan ini akan memberikan 
banyak keuntungan ekonomi. Namun apabila tidak dapat beradaptasi, negara tersebut akan beresiko mengalami ketertinggalan. Salah satu bentuk pemanfaatan teknologi ini adalah perdagangan berbasis online, atau yang biasa disebut sebagai e-commerce. Menurut Pasaribu et. al. (2017), ecommerce memiliki beberapa keunggulan jika dibandingkan dengan transaksi tradisional, yaitu: penghematan biaya, kemudahan akses informasi, dan penghematan waktu.

E-commerce sudah terbukti memberikan pengaruh positif terhadap pertumbuhan ekonomi suatu negara, seperti pada penelitian Georgiou (2009) di Eropa Barat, Liu (2013) di Cina, serta Ramzy \& Eldahan (2016) di Mesir. Selain meningkatkan pendapatan negara, e-commerce juga dapat memengaruhi sektor perekonomian, misalnya penyediaan jasa layanan antar atau logistik, penyediaan jasa telekomunikasi, produsen perangkat pintar, dan lain-lain. Untuk mendukung perkembangan e-commerce di Indonesia, pemerintah membuat paket kebijakan ekonomi XIV mengenai peta jalan sistem perdagangan nasional berbasis elektronik (road map ecommerce) pada November 2016.
Pemerintah memiliki visi untuk menempatkan Indonesia sebagai negara dengan kapasitas digital ekonomi terbesar di Asia Tenggara pada tahun 2020, yaitu bisa tercipta 1.000 technopreneurs dengan valuasi bisnis sebesar 10 miliar USD dengan nilai e-commerce mencapai 130 miliar USD.

Menurut Elseoud (2014), ada beberapa indikator yang dapat digunakan untuk melihat perkembangan e-commerce, di antaranya adalah pengguna internet, telepon seluler, dan komputer. Berdasarkan data Badan Pusat Statistik (BPS), 0,93\% penduduk Indonesia pada tahun 2000 menggunakan internet. Nilai tersebut meningkat secara perlahan hingga mencapai 25,37\% pada tahun 2016 . Selain pengguna internet, pengguna telepon seluler dan komputer juga mengalami peningkatan. Pada tahun 2011, sebesar 39,19\% penduduk memiliki telepon seluler, jumlahnya meningkat setiap tahunnya hingga menjadi 56,92\% pada tahun 2015 . Persentase rumah tangga yang menggunakan komputer juga mengalami peningkatan, dari yang semula hanya $12,3 \%$ pada tahun 2011 menjadi $18,71 \%$ pada 2015. 
Meskipun pengguna internet di Indonesia relatif tinggi, ternyata pengguna internet yang melakukan pembelian online masih relatif rendah. Berdasarkan data BPS, hanya $8,1 \%$ dari pengguna internet atau $3,18 \%$ dari total penduduk Indonesia melakukan pembelian secara online pada tahun 2017. Selain itu, persentase pembeli online menurut provinsi juga masih berbeda-beda. Penduduk yang tinggal di provinsi di Indonesia bagian timur yang melakukan pembelian online hanya sekitar $0,9 \%-1,5 \%$. Nilai tersebut cukup jauh jika dibandingkan dengan Provinsi DKI Jakarta, provinsi dengan persentase pembeli online terbanyak di Indonesia, yang sudah mencapai $8,93 \%$. Kondisi ini bisa menjadi salah satu penghambat tercapainya visi paket kebijakan ekonomi XIV. Oleh karena itu, perlu dilakukan pengkajian lebih lanjut untuk membahas faktor-faktor apa saja yang dapat memengaruhi persentase pembeli online di Indonesia.

Faktor-faktor yang memengaruhi keputusan seseorang untuk melakukan pembelian online antara lain infrastruktur (Hawk, 2004; Kurnia, 2006; Lawrence \& Tar, 2010; Dumičić et. al., 2014; Dumičić et. al., 2018), keadaan ekonomi atau pendapatan (Lawrence \&
Tar, 2010; Mahmood et. al., 2004; Akhter, 2015; Dumičić et. al., 2014), pendidikan (Lawrence \& Tar, 2010; Mahmood et. al., 2004), dan teknologi (Hawk, 2004; Kurnia, 2006; Mahmood et. al., 2004) atau penggunaan internet (Bellman et. al., 1999). Faktor-faktor tersebut bisa berpengaruh langsung dan atau tidak langsung terhadap keputusan seseorang untuk melakukan pembelian online.

Menurut Balabanis \& Vassileiou (1999), Sorce et. al. (2005), Brashear (2008), dan Kim et. al. (2012), pembeli online cenderung memiliki pendapatan yang lebih tinggi daripada orang yang tidak melakukannya. Selain itu, menurut Bellman et. al. (1999), Brashear (2008), dan Kim et. al. (2012), orang yang melakukan pembelian secara online memiliki tingkat pendidikan yang relatif lebih tinggi dibandingkan yang tidak melakukannya. Pendidikan juga dapat memengaruhi keadaan ekonomi (Purnastuti et. al., 2011; A'liyah, 2017; Taufiqurahman, 2018) dan kemampuan memanfaatkan teknologi (Chinn \& Fairlie, 2007; Billon et. al., 2009, Park et. al., 2015). Penduduk yang berpendidikan tinggi cenderung lebih mudah untuk beradaptasi dengan kemajuan teknologi. Dengan demikian, 
pendidikan bisa berpengaruh langsung dan tidak langsung terhadap keputusan seseorang untuk melakukan pembelian online.

Pengaruh teknologi terhadap keputusan seseorang untuk melakukan pembelian online dapat dijelaskan dengan menggunakan teori pencarian informasi konsumen (consumer information search theory) (Stigler, 1961). Strategi pencarian optimal dari konsumen ditunjukkan oleh trade off antara benefit yang diperoleh dan biaya untuk memperoleh informasi (Moorthy, Ratchford, \& Talukdar; 1997). Pada pasar persaingan sempurna, produk yang diproduksi homogen, harga produk ditentukan pasar, dan semua perusahaan bebas masuk dan keluar pasar (Pyndick \& Rubinfeld, 2007). Kenyataannya, produk yang dihasilkan produsen beragam dari segi kualitas dan harga. Perbedaan produk ini menghasilkan biaya tambahan yang digunakan untuk membandingkan produk-produk tersebut. Pada beberapa situasi, ketersediaan informasi tersebut terbatas dan membutuhkan biaya untuk mendapatkannya, sehingga informasi juga dapat dianggap sebagai barang ekonomi (Stigler, 1961). Meskipun mengeluarkan biaya tambahan, pencarian informasi dapat memberikan keuntungan yang lebih banyak untuk konsumen. Dengan meningkatnya informasi yang dimiliki, konsumen dapat menentukan produk yang akan dibeli sesuai dengan harga dan spesifikasi yang diinginkan, sehingga total kepuasannya meningkat. Semakin banyak pencarian yang dilakukan, akan semakin banyak manfaat yang didapatkan. Namun pertambahan manfaat ini turun seiring bertambahnya waktu yang dihabiskan untuk melakukan pencarian.

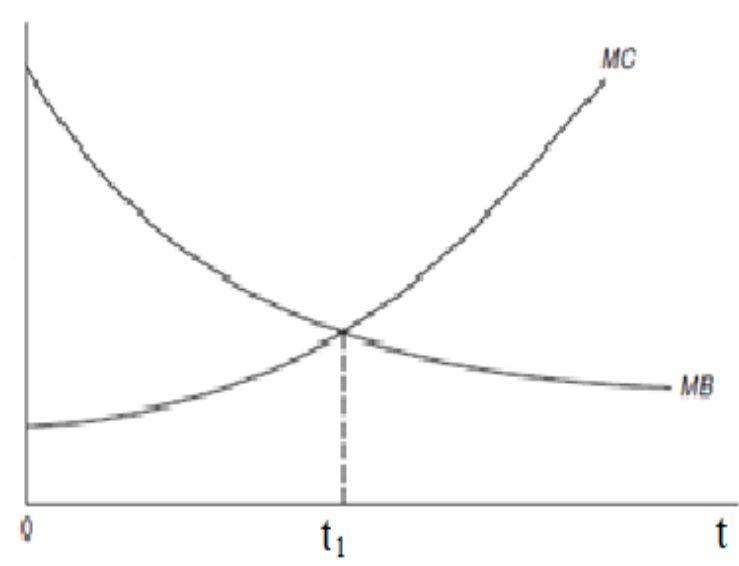

Gambar 1. MB dan MC untuk Pencarian Informasi

Sumber: Stigler (1961)

Gambar 1 menunjukkan nilai marginal cost (MC) dan marginal benefit (MB) yang diperoleh seiring bertambahnya waktu pencarian $(t)$. Net benefit akan mencapai titik maksimal ketika $M C$ sama dengan $M B$, yaitu pada $t_{1}$. Keadaan tersebut menunjukkan 
bahwa pertambahan manfaatnya $(M B)$ tidak lagi melebihi pertambahan biaya yang diperlukan $(M C)$, sehingga pencarian tidak perlu dilanjutkan.

Proses pencarian informasi dapat dengan mudah dilakukan dengan bantuan internet. Dengan memanfaatkan internet, konsumen tidak perlu mendatangi penjual secara langsung sehingga dapat mengurangi biaya pencarian. Biaya pencarian ini akan semakin berkurang seiring dengan meningkatnya kemampuan konsumen untuk memanfaatkan teknologi. Karena konsumen cenderung memilih barang dengan biaya total yang lebih rendah, maka konsumen cenderung akan memilih metode pembelian online yang memiliki biaya transaksi yang lebih rendah daripada pembelian secara langsung. Dengan demikian dapat dikatakan bahwa kemampuan penggunaan teknologi berpengaruh secara positif terhadap keputusan seseorang melakukan pembelian online.

Berdasarkan uraian di atas, ada beberapa faktor yang dapat memengaruhi keputusan seseorang untuk melakukan pembelian secara online. Namun, penelitian-penelitian tersebut hanya fokus untuk skala mikro.
Selain itu, selama ini penelitianpenelitian mengenai pembelian online di Indonesia hanya mencakup kota-kota besar saja. Oleh karena itu, pada peneliti tertarik untuk membahas mengenai gambaran pembelian online secara agregat atau kewilayahan di Indonesia serta kemungkinan faktorfaktor yang memengaruhinya dengan menggunakan data level provinsi. Dengan mengetahui faktor-faktor tersebut, dapat diperoleh rekomendasi kebijakan yang dapat mendorong perkembangan bisnis e-commerce di Indonesia.

\section{METODE}

Seperti yang sudah dijelaskan di pendahuluan, tingkat pendidikan, pendapatan, dan kemampuan seseorang dalam memanfaatkan teknologi dapat memengaruhi keputusan seseorang untuk melakukan pembelian secara online. Secara agregat, tingkat pembelian online di suatu wilayah dapat terlihat dari persentase penduduk yang melakukan pembelian secara online di wilayah tersebut. Pada penelitian ini, persentase pembeli online diwakili oleh jumlah penduduk berusia lima tahun ke atas (per total penduduk) yang menggunakan internet dalam tiga bulan 
terakhir dan pernah menggunakannya dengan tujuan untuk pembelian barang/jasa. Faktor pendapatan, pendidikan, dan teknologi masingmasing diwakili oleh variabel pendapatan perkapita, rata-rata lama sekolah, dan persentase pengguna internet. Pendapatan perkapita adalah rata-rata pendapatan yang diterima seorang pekerja dari pekerjaan utamanya sebulan yang lalu. Sedangkan rata-rata lama sekolah adalah rata-rata tahun belajar penduduk usia 25 tahun keatas yang telah diselesaikan dalam pendidikan formal (tidak termasuk tahun yang mengulang). Persentase penduduk yang menggunakan internet adalah persentase penduduk berusia lima tahun keatas yang pernah mengakses internet dalam tiga bulan terakhir, terlepas dari perangkat yang digunakan (bisa melalui komputer, telepon seluler, tablet, personal digital assistant, mesin game, televisi digital, dan lain-lain) serta akses bisa melalui jaringan tetap atau berpindah-pindah.

Data yang digunakan merupakan data cross section yang meliputi 34 provinsi di Indonesia pada tahun 2017.
Persentase pengguna internet dan persentase pembeli online diperoleh dari hasil pengolahan data Survei Sosial Ekonomi Nasional (Susenas). Pendapatan perkapita diperoleh dari hasil pengolahan data Survei Angkatan Kerja Nasional (Sakernas). Peneliti melakukan estimasi data level provinsi dengan menggunakan data mentah Susenas-Sakernas dan penimbang yang diperoleh dari BPS. Sedangkan rata-rata lama sekolah didapatkan dari publikasi BPS.

Metode analisis jalur digunakan untuk mengetahui dampak langsung dan tidak langsung dari pendapatan perkapita, rata-rata lama sekolah, dan persentase pengguna internet terhadap persentase penduduk yang melakukan pembelian online. Analisis jalur dipilih karena persamaan pada penelitian ini memiliki hubungan sebab-akibat yang kompleks. Beberapa variabel memiliki peran ganda, yaitu menjadi variabel bebas di suatu persamaan dan menjadi variabel terikat pada persamaan lain. Penelitian ini mengacu pada persamaan Mahmood et. al. (2004) dengan modifikasi. Diagram jalur pada penelitian ini bisa dilihat di Gambar 2. 


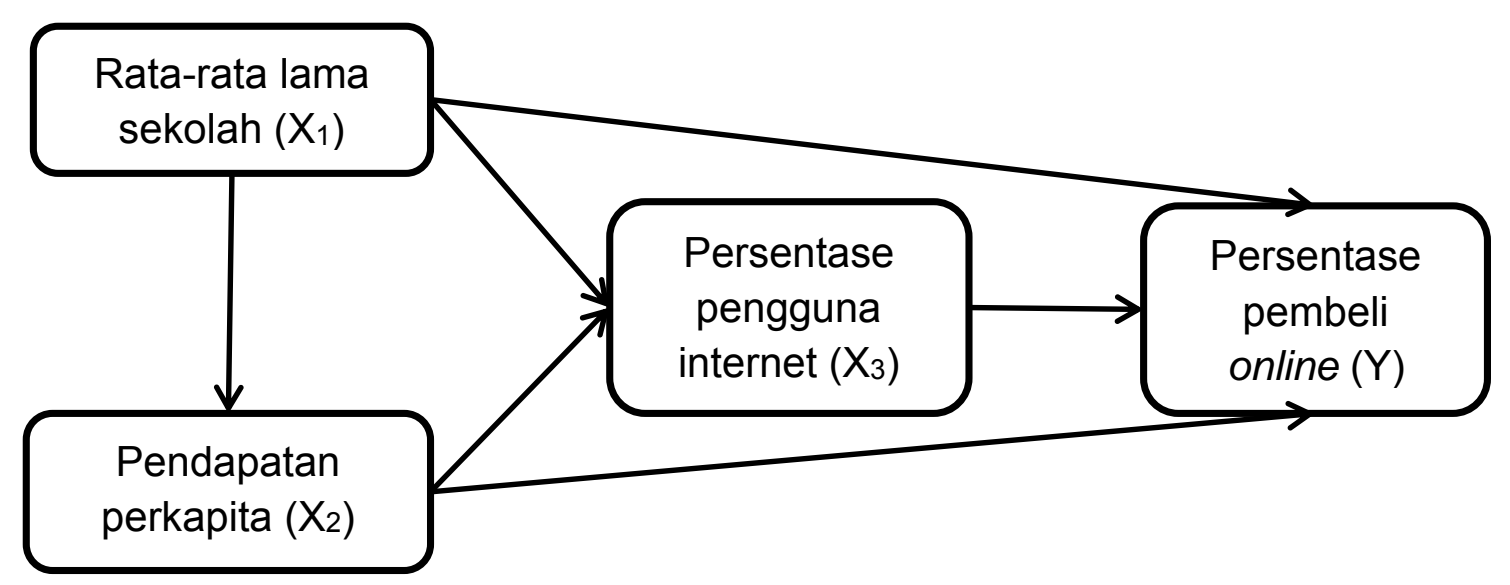

\section{Gambar 2. Diagram Jalur Variabel-Variabel dalam Penelitian}

Model pada penelitian ini terdiri dari tiga persamaan, yaitu: persamaan pendapatan perkapita, persamaan persentase pengguna internet, dan persamaan persentase pembeli online. Persamaan-persamaan tersebut dapat dilihat di persamaan 1, 2, dan 3 . Sedangkan penghitungan dampak langsung, dampak tidak langsung, dan dampak total variabel-variabel pada penelitian ini dapat dilihat di Tabel 1.

$X_{2 i}=\rho_{X_{2} X_{1}} X_{1 i}+\varepsilon_{1 i}$

$X_{3 i}=\rho_{X_{3} X_{1}} X_{1 i}+\rho_{X_{3} X_{2}} X_{2 i}+\varepsilon_{2 i}$

$Y_{i}=\rho_{Y X_{1}} X_{1 i}+\rho_{Y X_{2}} X_{2 i}+\rho_{Y X_{3}} X_{3 i}+\varepsilon_{3 i}(3)$

dimana:

$X_{1 \mathrm{i}}$ : rata-rata lama sekolah pada provinsi $i$ (tahun)

$X_{2 \mathrm{i}}$ : pendapatan perkapita pada provinsi $i$ (juta rupiah)

$X_{3 i}$ : persentase pengguna internet pada provinsi $i$
$Y_{i}:$ persentase pembeli online pada provinsi $i$

$\rho_{Y X_{1}}$ : koefisien jalur dari variabel $X_{1}$ terhadap variabel $Y$

$\rho_{Y X_{2}}$ : koefisien jalur dari variabel $X_{2}$ terhadap variabel $Y$

$\rho_{Y X_{3}}$ : koefisien jalur dari variabel $X_{3}$ terhadap variabel $Y$

$\rho_{X_{3} X_{1}}$ : koefisien jalur dari variabel $X_{1}$ terhadap variabel $X_{3}$

$\rho_{X_{3} X_{2}}$ : koefisien jalur dari variabel $X_{2}$ terhadap variabel $X_{3}$

$\rho_{X_{2} X_{1}}$ : koefisien jalur dari variabel $X_{1}$ terhadap variabel $X_{2}$

$\varepsilon_{1}$ : residual persamaan pendapatan perkapita

$\varepsilon_{2}$ : residual persamaan persentase pengguna internet

$\varepsilon_{3}$ : residual persamaan persentase pembeli online 
Tabel 1. Penghitungan Dampak Langsung, Dampak Tidak Langsung, dan Dampak Total Antar Variabel-Variabel dalam Penelitian

\begin{tabular}{|c|c|c|c|c|}
\hline \multirow[b]{2}{*}{$\begin{array}{l}\text { Variabel } \\
\text { Terikat }\end{array}$} & \multirow[b]{2}{*}{ Variabel Bebas } & \multirow[b]{2}{*}{$\begin{array}{l}\text { Dampak } \\
\text { Langsung }\end{array}$} & \multicolumn{2}{|c|}{ Dampak Tidak Langsung Melalui } \\
\hline & & & $\begin{array}{c}\text { Persentase } \\
\text { Pengguna } \\
\text { Internet }\end{array}$ & $\begin{array}{c}\text { Pendapatan } \\
\text { perkapita }\end{array}$ \\
\hline $\begin{array}{l}\text { Pendapatan } \\
\text { perkapita }\end{array}$ & Rata-rata lama sekolah & $\rho_{X_{2} X_{1}}$ & & \\
\hline \multirow{2}{*}{$\begin{array}{l}\text { Persentase } \\
\text { pengguna } \\
\text { internet }\end{array}$} & $\begin{array}{l}\text { 1. Rata-rata lama } \\
\text { sekolah }\end{array}$ & $\rho_{X_{3} X_{1}}$ & & $\rho_{X_{2} X_{1}} \cdot \rho_{X_{3} X_{2}}$ \\
\hline & $\begin{array}{l}\text { 2. Pendapatan } \\
\text { perkapita }\end{array}$ & $\rho_{X_{3} X_{2}}$ & & \\
\hline \multirow{3}{*}{$\begin{array}{l}\text { Persentase } \\
\text { pembeli } \\
\text { online }\end{array}$} & $\begin{array}{l}\text { 1. Rata-rata lama } \\
\text { sekolah }\end{array}$ & $\rho_{Y X_{1}}$ & \multirow{3}{*}{$\begin{array}{c}\rho_{X_{3} X_{1}} \cdot \rho_{Y X_{3}}+ \\
\rho_{X_{2} X_{1}} \cdot \rho_{X_{3} X_{2}} \cdot \rho_{Y X_{2}} \\
\quad \rho_{X_{3} X_{2}} \cdot \rho_{Y X_{3}}\end{array}$} & $\rho_{X_{2} X_{1}} \cdot \rho_{Y X_{2}}$ \\
\hline & $\begin{array}{l}\text { 2. Pendapatan } \\
\text { perkapita }\end{array}$ & $\rho_{Y X_{2}}$ & & \\
\hline & $\begin{array}{l}\text { 3. Persentase } \\
\text { pengguna internet }\end{array}$ & $\rho_{Y X_{3}}$ & & \\
\hline
\end{tabular}

HASIL DAN PEMBAHASAN

Gambaran Umum Persentase

Pembeli Online di Indonesia Tahun

2017 dan Faktor-Faktor yang

\section{Memengaruhinya}

Persentase pembeli online di Indonesia pada tahun 2017 termasuk masih rendah. Berdasarkan data BPS, seperti yang ditunjukkan di Gambar 3, hanya $8,1 \%$ pengguna internet atau $2,62 \%$ penduduk Indonesia yang melakukan pembelian secara online. Meskipun rendah, persentase pembeli online di Indonesia bervariasi menurut provinsi dengan persentase terendah di
Maluku ( $0,91 \%$ pengguna internet) dan persentase tertinggi di DKI Jakarta (8,93\% pengguna internet).

Berdasarkan data International Telecommunication Union (ITU), terjadi pertumbuhan pengguna internet yang cukup pesat selama beberapa tahun terakhir. Pada tahun 2000, 0,93\% penduduk Indonesia menggunakan internet. Nilai tersebut meningkat secara perlahan hingga mencapai $6,92 \%$ pada tahun 2009 dan 10,92\% pada tahun 2010. Bahkan pada tahun 2017, persentase pengguna internet di Indonesia mencapai $32,34 \%$. 
Tabel 2. Jumlah Desa/Kelurahan yang Mendapatkan Sinyal Telepon Selular dan Persentasenya Terhadap Total Desa/Kelurahan di Indonesia menurut Kekuatan Penerimaan Sinyal, 2008, 2011, dan 2014

\begin{tabular}{cccc}
\hline Tahun & Sinyal Kuat & Sinyal Lemah & Tidak Ada Sinyal \\
\hline 2008 & $48.382(64,16 \%)$ & $17.330(22,98 \%)$ & $9.698(12,86 \%)$ \\
2011 & $53.338(67,85 \%)$ & $17.272(21,97 \%)$ & $7.999(10,19 \%)$ \\
2014 & $55.870(67,98 \%)$ & $18.603(22,63 \%)$ & $7,717(9,39 \%)$ \\
\hline
\end{tabular}

Sumber: BPS (2016)

Tabel 3. Persentase Desa/Kelurahan yang Mendapatkan Sinyal Telepon Selular di Indonesia menurut Kekuatan Penerimaan Sinyal dan Wilayah, 2008 dan 2014

\begin{tabular}{lrrrrrr}
\hline \multirow{2}{*}{ Wilayah } & \multicolumn{3}{c}{2008} & & 2014 & \\
\cline { 2 - 7 } & $\begin{array}{c}\text { Sinyal } \\
\text { Kuat }\end{array}$ & $\begin{array}{c}\text { Sinyal } \\
\text { Lemah }\end{array}$ & $\begin{array}{c}\text { Tidak } \\
\text { Ada } \\
\text { Sinyal }\end{array}$ & $\begin{array}{c}\text { Sinyal } \\
\text { Kuat }\end{array}$ & $\begin{array}{c}\text { Sinyal } \\
\text { Lemah }\end{array}$ & $\begin{array}{c}\text { Tidak } \\
\text { Ada } \\
\text { Sinyal }\end{array}$ \\
\hline Sumatera & 63,41 & 30,38 & 6,21 & 71,41 & 26,09 & 2,51 \\
Jawa & 86,32 & 13,05 & 0,63 & 85,13 & 14,4 & 0,46 \\
Bali dan Nusa Tenggara & 60,19 & 28,23 & 11,59 & 62,55 & 31,01 & 6,44 \\
Kalimantan & 50,33 & 31,89 & 17,78 & 52,97 & 34,13 & 12,91 \\
Sulawesi & 52,42 & 29,8 & 17,78 & 66,22 & 25,89 & 7,9 \\
Maluku dan Papua & 14,35 & 12,23 & 73,41 & 25,93 & 18,16 & 55,9 \\
\hline
\end{tabular}

Sumber: BPS (2016)

Penggunaan internet di Indonesia bertambah seiring dengan meningkatnya jangkauan layanan internet. Berdasar data BPS (Tabel 2), pada tahun 2014 sebesar 90,61\% desa/kelurahan di Indonesia dapat menerima sinyal telepon selular. Jumlah ini meningkat jika dibandingkan pada tahun 2008 dan 2011, yaitu masingmasing sebesar $87,14 \%$ dan $89,82 \%$.

Layanan sinyal telepon selular juga mengalami perbaikan, ditunjukkan dari semakin banyaknya desa/kelurahan yang dapat menerima sinyal kuat. Pada tahun 2014, sebanyak 67,98\% desa/kelurahan menerima sinyal kuat. Persentase ini meningkat dibanding tahun 2008 yang hanya sebesar $64,16 \%$. Persentase desa/kelurahan yang tidak dapat menerima sinyal juga semakin menurun dari tahun ke tahun. Persentase desa/kelurahan yang tidak dapat menerima sinyal pada tahun 2008, 2011, dan 2014 adalah masing-masing $12,86 \% ; 10,18 \%$; dan $9,39 \%$. 
Jawa merupakan wilayah dengan persentase desa/kelurahan yang menerima sinyal selular tertinggi dibandingkan dengan wilayah lain di Indonesia, diikuti Sumatera, Sulawesi, Bali dan Nusa Tenggara, serta
Kalimantan. Sedangkan Maluku dan Papua merupakan wilayah dengan persentase desa/kelurahan yang menerima sinyal telepon selular terendah (lihat tabel 3).

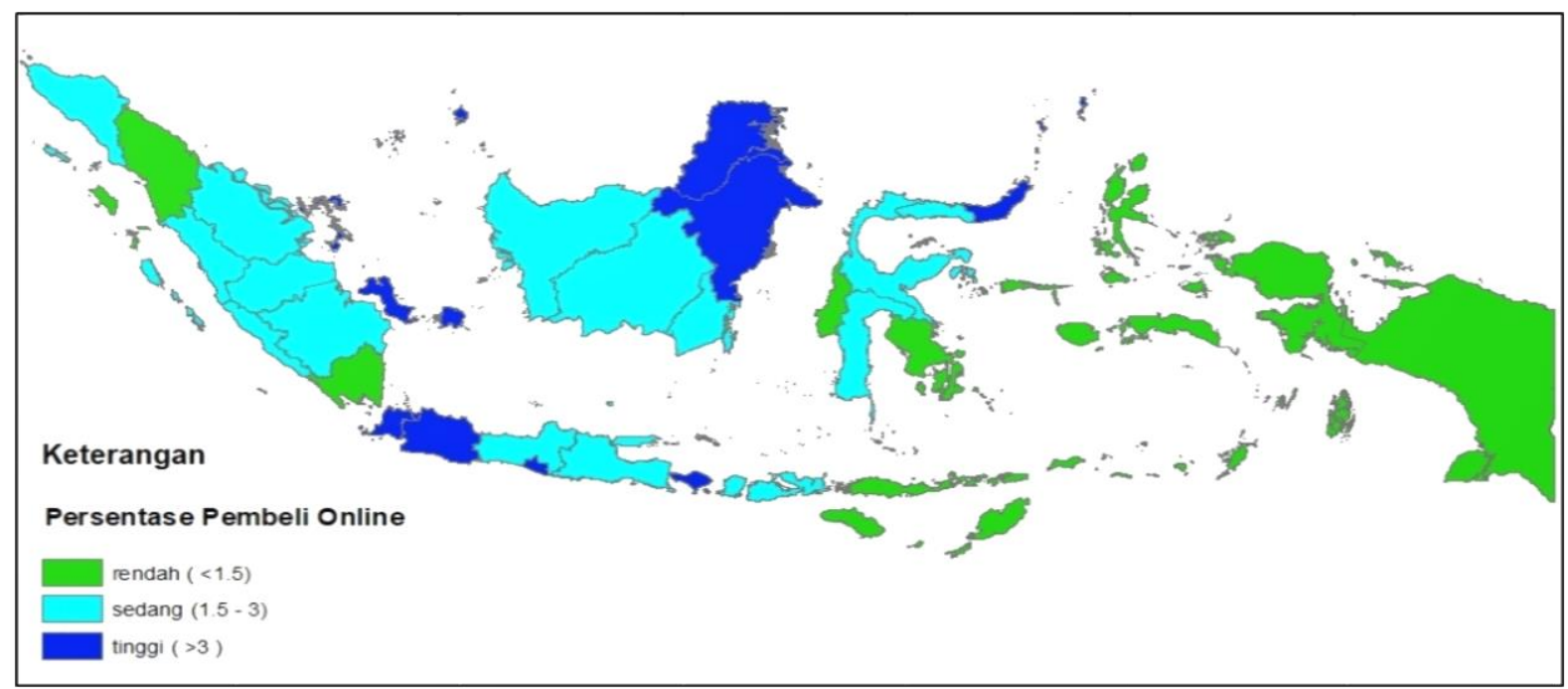

Gambar 3. Persentase Pembeli Online Terhadap Pengguna Internet di Indonesia Menurut Provinsi, Tahun 2017

Sumber: BPS (2018), diolah

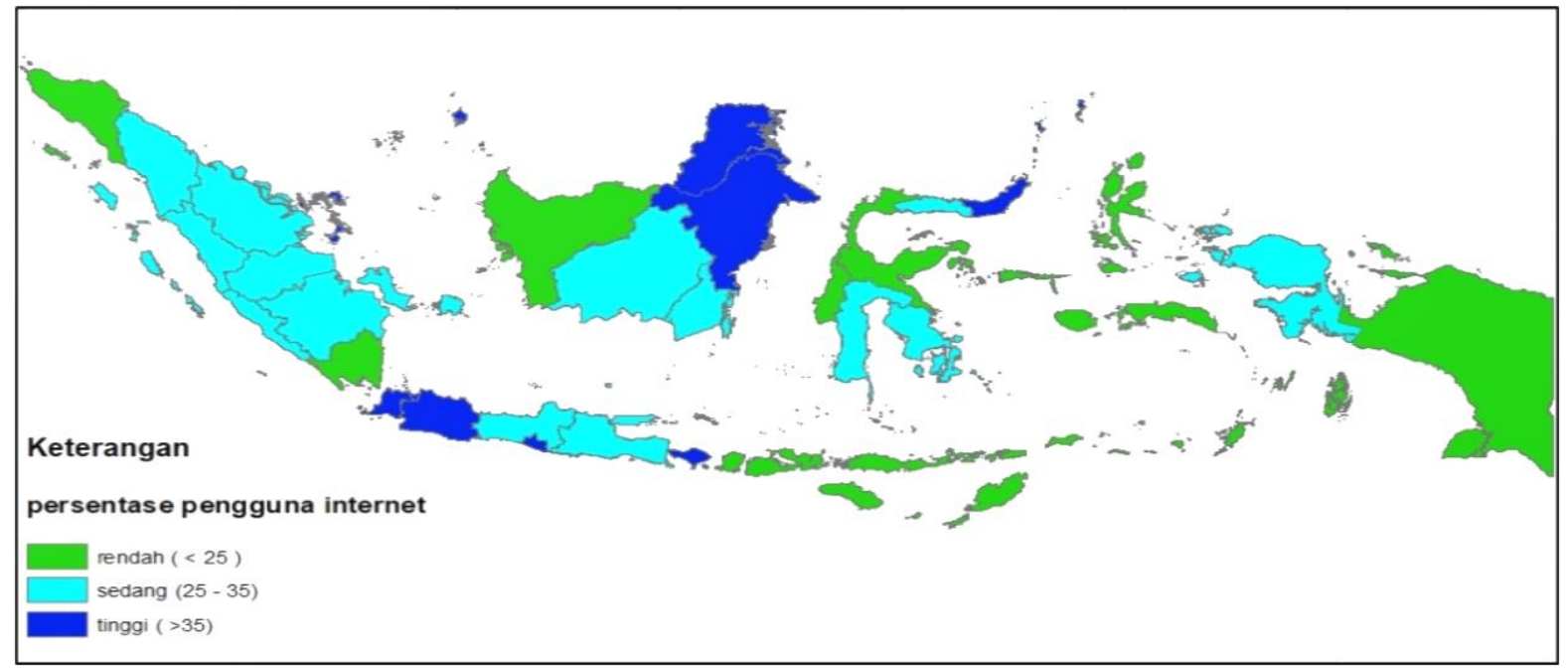

Gambar 4. Persentase Pengguna Internet Terhadap Total Penduduk di Indonesia Menurut Provinsi, Tahun 2017

Sumber: BPS (2018), diolah 
Perbedaan penerimaan sinyal telepon selular kemungkinan menjadi salah satu penyebab adanya perbedaan persentase pengguna internet antar provinsi di Indonesia. Persentase pengguna internet terhadap total penduduk pada provinsi di Indonesia bagian barat dan tengah secara umum termasuk kategori tinggi dan sedang. Bahkan, persentase penduduk Provinsi DKI Jakarta dan Kepulauan Riau yang menggunakan internet adalah masingmasing $60,65 \%$ dan $48,35 \%$. Sedangkan persentase pengguna internet di Provinsi Maluku Utara, Nusa Tenggara Timur, dan Papua menempati urutan tiga terbawah, yaitu masing-masing $18,8 \%$; $17,88 \%$; dan $16,51 \%$. Berdasarkan Gambar 3 dan 4, terlihat bahwa provinsi yang memiliki persentase pengguna internet rendah akan cenderung memiliki persentase pembeli online rendah, dan sebaliknya.

Pendapatan perkapita di Indonesia sebesar 988.896 rupiah perbulan. Provinsi dengan pendapatan perkapita tertinggi adalah DKI Jakarta, yaitu 1.966.301 rupiah. Sedangkan provinsi dengan pendapatan perkapita terendah adalah Nusa Tenggara Timur, yaitu 458,294 rupiah. Berdasarkan Gambar 3, 4, dan 5, dapat disimpulkan bahwa semakin tinggi pendapatan perkapita maka persentase pengguna internet dan persentase pembeli online-nya juga semakin tinggi. Hasil tersebut didukung dengan nilai korelasi Pearson yang tinggi antara pendapatan perkapita dengan persentase pengguna internet dan antara pendapatan perkapita dengan persentase pembeli online yaitu masingmasing sebesar $0,83 \%$ dan $0,81 \%$.

Berdasarkan data BPS, rata-rata lama sekolah di Indonesia pada tahun 2017 sebesar 8,1 tahun, atau setara dengan kelas dua Sekolah Menengah Pertama (SMP)/sederajat. Angka ini dikatakan cukup rendah, mengingat program wajib belajar sembilan tahun telah dilaksanakan sejak lama. Besarnya nilai rata-rata lama sekolah tidak terlalu bervariasi antar provinsi. Hal ini ditunjukkan dari nilai koefisien variasi yang hanya sebesar 0,117.

Gambar 6 menunjukkan pengelompokan provinsi berdasarkan rata-rata lama sekolah. Dari gambar tersebut dapat diketahui bahwa pola pengelompokannya sedikit berbeda dengan tiga pengelompokan yang sudah dibahas sebelumnya. Perbedaannya terletak pada kawasan Jawa dan Maluku. Jika sebelumnya Maluku yang pada pengelompokan 
persentase pembeli online dan serupa, secara umum masih sama. persentase pengguna internet termasuk Papua dan Nusa Tenggara Timur masih pada kategori rendah, pada tertinggal dibanding provinsi lain. pengelompokan ini termasuk pada Gambar 3, 4, 5, dan 6 menunjukkan kelompok tinggi. Selain itu, provinsi- pola yang sama. Hal tersebut sesuai provinsi di Pulau Jawa yang dengan nilai korelasi Pearson yang sebelumnya mayoritas termasuk pada tinggi antara rata-rata lama sekolah kategori sedang dan tinggi, justru dengan persentase pengguna internet, ada dua provinsi yang termasuk pada pendapatan perkapita, dan persentase rata-rata lama sekolah kategori rendah. pembeli online, yaitu masing-masing Meskipun polanya tidak sepenuhnya 0,$71 ; 0,64$; dan 0,63 .

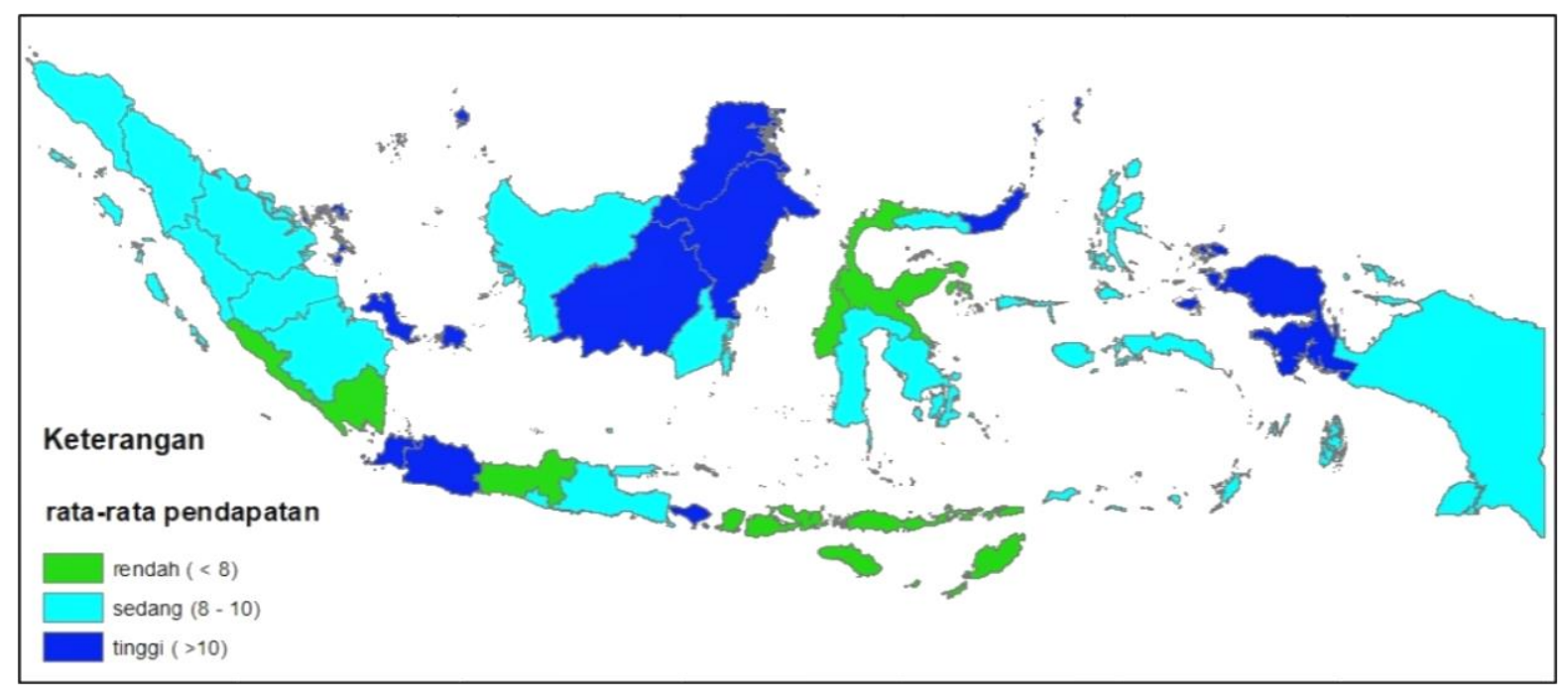

Gambar 5. Pendapatan Perkapita per Bulan di Indonesia Menurut Provinsi, Tahun 2017

Sumber: BPS (2018), diolah 


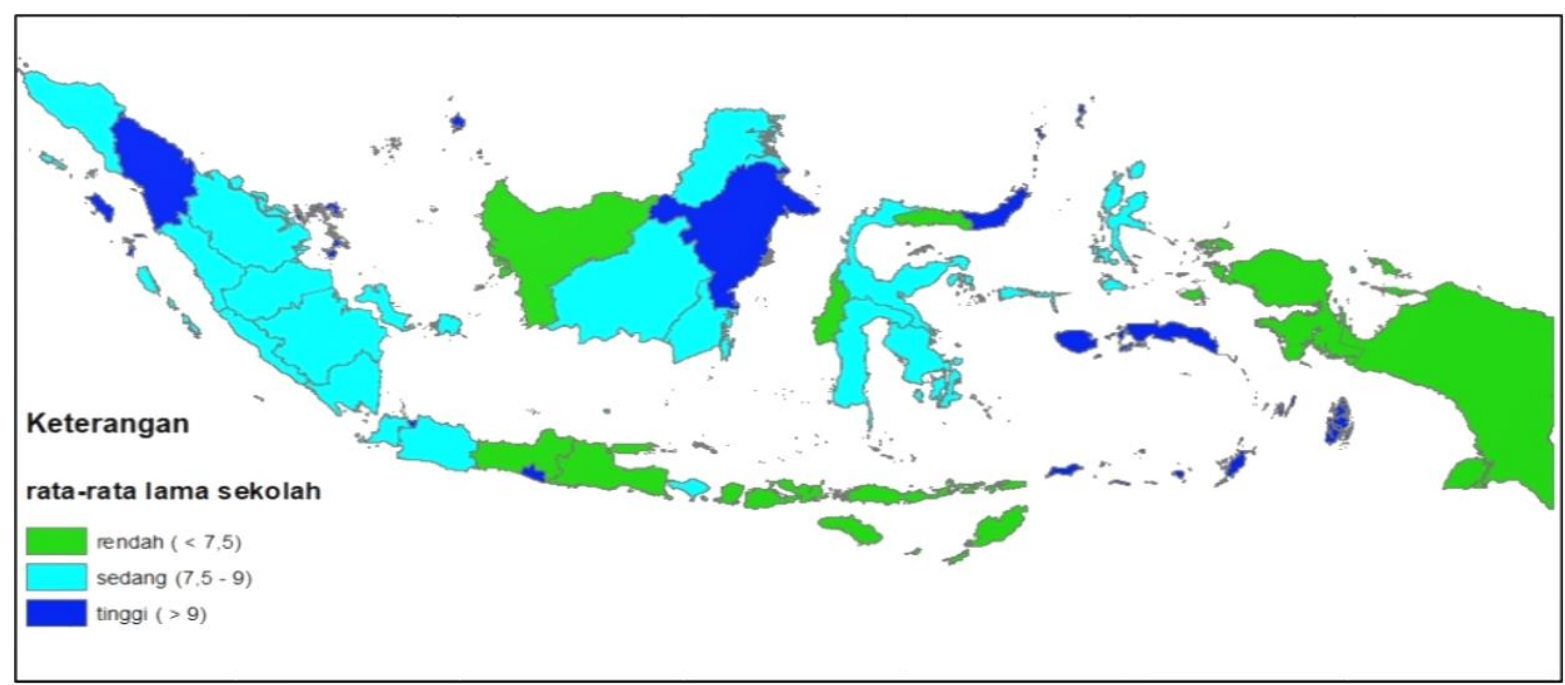

Gambar 6. Rata-rata Lama Sekolah di Indonesia Menurut Provinsi, Tahun 2017

Sumber: BPS (2018), diolah

Hasil Estimasi dengan Model Analisis Jalur

Pada penelitian ini akan dilakukan analisis inferensia dengan metode analisis jalur untuk mengetahui variabelvariabel yang memengaruhi persentase pembeli online. Hasil estimasi koefisien variabel yang memengaruhi persentase pembeli online bisa dilihat di Tabel 4 dan diagram jalurnya pada Gambar 7.

Pada persamaan persentase pembeli online, nilai $p$-value untuk uji $\mathrm{F}$ bernilai kurang dari tingkat signifikansi $5 \%$. Hal ini berarti bahwa setidaknya ada satu variabel di antara variabel rata-rata lama sekolah, pendapatan perkapita, dan persentase pengguna internet yang memengaruhi persentase pembeli online. Selain itu, pada persamaan persentase pembeli online diperoleh $\mathrm{R}^{2}$ sebesar 0,831 yang menunjukkan bahwa model yang terbentuk cukup baik karena variasi persentase pembeli online dapat dijelaskan oleh model sebesar $83,1 \%$, sedangkan $16,7 \%$ lainnya dijelaskan oleh variabel lain di luar model. Namun berdasarkan hasil uji parsial masing-masing variabel, variabel yang berpengaruh signifikan terhadap persentase pembeli online hanya variable persentase pengguna internet. Oleh karena itu, persamaan tersebut perlu diperbaiki melalui proses trimming. Proses trimming dilakukan dengan cara mengestimasi ulang tanpa melibatkan variabel bebas yang tidak signifikan. 
Tabel 4. Hasil Estimasi Koefisien Jalur

\begin{tabular}{llcccc}
\hline \multicolumn{1}{c}{$\begin{array}{c}\text { Variabel } \\
\text { Terikat }\end{array}$} & \multicolumn{1}{c}{ Variabel Bebas } & $\begin{array}{c}\text { Estimasi } \\
\text { Koefisien } \\
\text { Jalur }\end{array}$ & $\begin{array}{c}p- \\
\text { value } \\
\text { uji t }\end{array}$ & $\mathrm{R}^{2}$ & $\begin{array}{c}p \text {-value } \\
\text { uji F }\end{array}$ \\
\hline Pendapatan & Rata-rata lama sekolah & 0,626 & 0,000 & 0,391 & 0,000 \\
perkapita & Rata-rata lama sekolah & 0,311 & 0,011 & & \\
Persentase & & 0,639 & 0,000 & 0,753 & 0,000 \\
pengguna & Pendapatan perkapita & & \\
internet & Rata-rata lama sekolah & -0.010 & 0,927 & & \\
Persentase & $\begin{array}{c}0,173 \\
\text { pembeli }\end{array}$ & $\begin{array}{c}0,214 \\
\text { Pendapatan perkapita }\end{array}$ & 0,831 & 0,000 \\
\hline online & Persentase pengguna internet & 0,793 & 0,000 & & \\
\hline
\end{tabular}

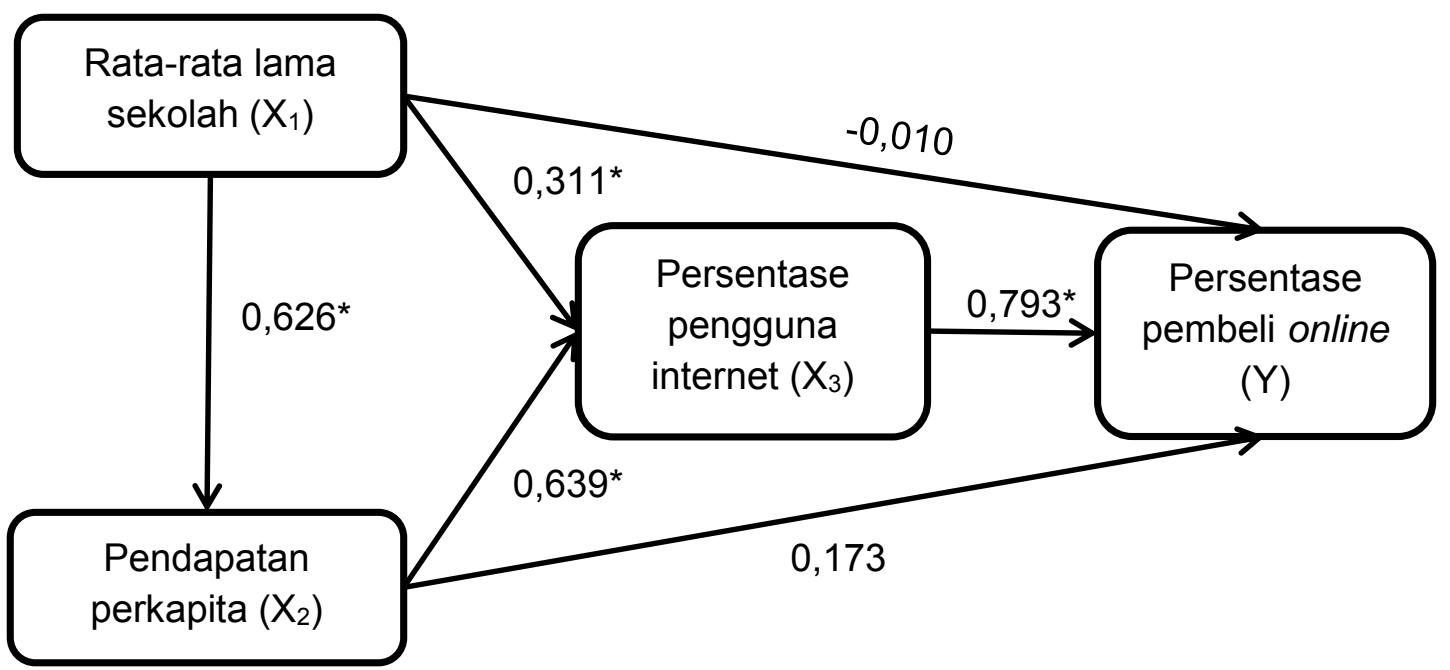

\section{Gambar 7. Diagram Jalur Hasil Estimasi Koefisien Jalur}

Keterangan: *) signifikan pada $\alpha=5 \%$

Setelah dilakukan proses trimming, perlu dilakukan pengujian kesesuaian model untuk model baru (reproduced model) dengan menghitung nilai $\mathrm{Q}$.

$R_{m}^{2}=1-(1-0,831) \cdot(1-0,753)$.

$(1-0,391)=0,975$.

$M=1-(1-0,822) \cdot(1-0,753) \cdot(1-$

$0,391)=0,973$

$Q=\frac{1-R_{m}^{2}}{1-M}=\frac{1-0,975}{1-0,974}=\frac{0,0251}{0,0263}=0,949$

Nilai $Q$ yang mendekati satu mengindikasikan bahwa model yang baru sesuai (fit) dengan data (Dillon \& Goldstein, 1984). Bentler \& Bonett (1980) menyatakan bahwa model yang baru fit jika nilai $Q$ lebih dari 0,9 . Selain itu, Bentler dan Bonett (1980); Dillon \& Goldstein (1984) menyatakan bahwa chi-square goodness of fit test mendapatkan kritikan karena sensitivitasnya terhadap jumlah sampel. Ketika jumlah sampel meningkat dengan asumsi nilai $Q$ konstan, maka nilai statistik $\mathrm{W}$ akan meningkat. Akibatnya, 
jumlah observasi yang kecil akan cenderung memberikan keputusan model yang baru tidak sesuai (tidak fit) dengan data. Karena penelitian ini memiliki jumlah observasi yang kecil, yaitu 34, peneliti tidak menggunakan statistik W untuk menentukan model fit atau tidak dan hanya menggunakan nilai Q. Berdasarkan perhitungan, diperoleh nilai $Q$ sebesar 0,949 dan dapat disimpulkan bahwa model yang baru sesuai (fit) dengan data.

Tabel 5 menunujukkan persentase pengguna internet memengaruhi persentase pembeli online secara signifikan, ditunjukkan oleh $p$-value uji t yang nilainya kurang dari tingkat signifikansi $5 \%$. Selain itu, model yang terbentuk sudah cukup bagus karena $82,2 \%$ variasi persentase pembeli online dapat dijelaskan oleh variabel persentase pengguna internet, sedangkan $17,8 \%$ lainnya dijelaskan oleh variabel lain di luar model. Dengan demikian, persamaan ini sudah memenuhi asumsi klasik (residual berdistribusi normal dan homoskedastis).

\section{Tabel 5. Hasil Estimasi Koefisien Jalur Setelah Dilakukan Proses Trimming}

\begin{tabular}{|c|c|c|c|c|c|}
\hline Variabel Terikat & Variabel Bebas & $\begin{array}{c}\text { Estimasi } \\
\text { Koefisien } \\
\text { Jalur }\end{array}$ & $\begin{array}{c}p- \\
\text { value } \\
\text { uii t }\end{array}$ & $\mathrm{R}^{2}$ & $\begin{array}{c}p \text {-value } \\
\text { uji F }\end{array}$ \\
\hline \multirow{3}{*}{$\begin{array}{l}\text { Pendapatan } \\
\text { perkapita } \\
\text { Persentase } \\
\text { pengguna internet } \\
\text { Persentase } \\
\text { pembeli online }\end{array}$} & Rata-rata lama sekolah & 0,626 & 0,000 & 0,391 & 0,000 \\
\hline & \multirow{2}{*}{$\begin{array}{l}\text { Rata-rata lama sekolah } \\
\text { Pendapatan perkapita } \\
\text { Persentase pengguna } \\
\text { internet }\end{array}$} & $\begin{array}{l}0,311 \\
0,639\end{array}$ & $\begin{array}{l}0,011 \\
0,000\end{array}$ & 0,753 & 0,000 \\
\hline & & 0,907 & 0,000 & 0,822 & 0,000 \\
\hline
\end{tabular}

Model persamaan struktural persentase pengguna internet juga dapat dikatakan sudah baik. Hal ini dibuktikan dengan nilai $p$-value untuk uji $F$ yang kurang dari $5 \%$ dan nilai $R^{2}$ yang cukup tinggi, yaitu sebesar 0,753 . Selain itu, semua variabel bebasnya juga siginifikan secara parsial, yang ditunjukkan oleh hasil uji t untuk masingmasing variabel bernilai kurang dari $5 \%$.
Persamaan ini juga sudah memenuhi asumsi klasik.

Persamaan pendapatan perkapita juga sudah cukup baik. Berdasarkan Tabel 5, nilai $p$-value untuk uji F dan uji $t$ kurang dari $5 \%$. Hal ini berarti variabel rata-rata lama sekolah memengaruhi pendapatan perkapita secara signifikan. Persamaan ini juga sudah memenuhi asumsi klasik. 


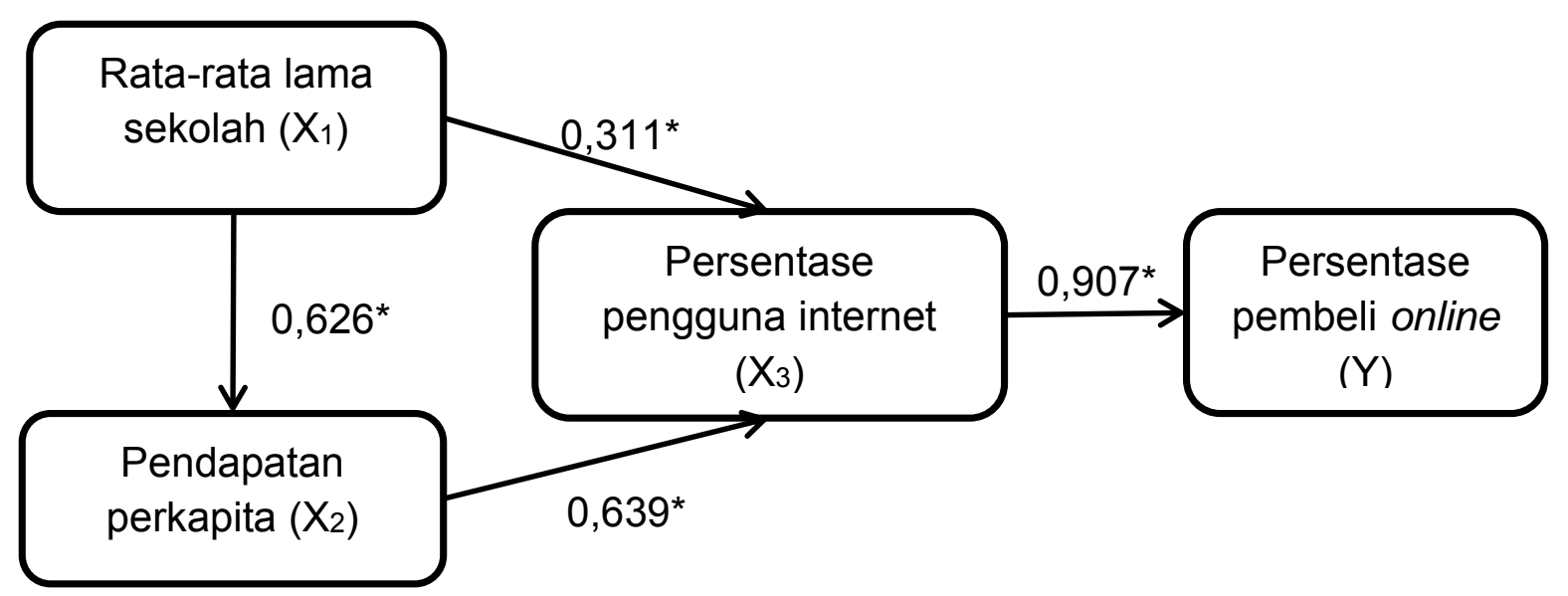

\section{Gambar 8. Diagram Jalur Hasil Estimasi Koefisien Jalur Setelah Dilakukan Proses Trimming}

Keterangan: *)signifikan pada $\alpha=5 \%$

Gambar 8 menunjukkan diagram jalur setelah dilakukan proses trimming. Persamaan struktural dari diagram jalur tersebut dapat dilihat di persamaan 7,8 , dan 9.

$\widehat{X}_{2}=0,626 X_{1}$

$\hat{X}_{3}=0,311 X_{1}+0,639 X_{2}$

$\hat{Y}=0,907 X_{3}$

Koefisien determinasi total untuk sistem persamaan struktural ini sebesar

$\mathrm{R}_{m}^{2}=1-(1-0,822) \times(1-0,753) \times$ $(10,391)=0,975$.
Koefisien determinasi total $\left(R^{2} \mathrm{~m}\right)$ sebesar 0,975 menunjukkan bahwa model tersebut dapat menjelaskan $97,5 \%$ informasi yang terkandung dalam data, sementara sisanya dijelaskan oleh variabel lain di luar model. Dengan demikian, dapat disimpulkan bahwa model yang terbentuk sudah sangat baik. Pengaruh langsung dan tidak langsung antar variabel pada model tersebut dapat dilihat pada Tabel 6.

Tabel 6. Pengaruh Langsung dan Tidak Langsung antar Variabel-Variabel dalam Penelitian

\begin{tabular}{|c|c|c|c|c|c|}
\hline \multirow{2}{*}{$\begin{array}{l}\text { Variabel } \\
\text { Terikat }\end{array}$} & \multirow{2}{*}{ Variabel Bebas } & \multirow{2}{*}{$\begin{array}{l}\text { Dampak } \\
\text { Langsung }\end{array}$} & \multicolumn{2}{|c|}{ Dampak Tidak Langsung } & \multirow{2}{*}{$\begin{array}{c}\text { Dampak } \\
\text { Total }\end{array}$} \\
\hline & & & Melalui & Nilai & \\
\hline $\begin{array}{l}\text { Pendapatan } \\
\text { perkapita }\end{array}$ & Rata-rata lama sekolah & 0,626 & & & 0,626 \\
\hline \multirow{2}{*}{$\begin{array}{l}\text { Persentase } \\
\text { pengguna } \\
\text { internet }\end{array}$} & Rata-rata lama sekolah & 0,311 & $\begin{array}{l}\text { Pendapatan } \\
\text { perkapita }\end{array}$ & 0,400 & 0,711 \\
\hline & $\begin{array}{l}\text { Pendapatan perkapita } \\
\text { Rata-rata lama sekolah }\end{array}$ & 0,639 & Persentase & 0,645 & $\begin{array}{l}0,639 \\
0,645\end{array}$ \\
\hline \multirow{2}{*}{$\begin{array}{l}\text { Persentase } \\
\text { pembeli } \\
\text { online }\end{array}$} & Pendapatan perkapita & & $\begin{array}{l}\text { pengguna } \\
\text { internet }\end{array}$ & 0,580 & 0,580 \\
\hline & $\begin{array}{l}\text { Persentase pengguna } \\
\text { internet }\end{array}$ & 0,907 & & & 0,907 \\
\hline
\end{tabular}


Berdasarkan hasil estimasi pada Tabel 6, diketahui bahwa persentase pengguna internet merupakan satusatunya variabel dalam penelitian yang mempunyai pengaruh langsung dan signifikan terhadap persentase pembeli online. Variabel ini merupakan variabel yang memiliki pengaruh paling dominan pada persentase pembeli online. Hal ini ditunjukkan dari nilai dampak totalnya yang paling besar jika dibandingkan dengan variabel lain, yaitu sebesar 0,907. Selain itu, variabel ini dapat menjelaskan $82,2 \%$ variasi dari persentase pembeli online yang tergambar pada nilai $\mathrm{R}^{2}$ dari persamaan tersebut. Koefisien jalur dari persentase pengguna internet terhadap persentase pembeli online sebesar 0,907. Nilai koefisien jalur yang lebih dari nol menunjukkan bahwa variabel tersebut berpengaruh secara positif. Jika persentase pengguna internet meningkat, persentase pembeli online juga akan meningkat. Hal ini sesuai dengan hasil analisis deskriptif yang telah dijelaskan sebelumnya (lihat Gambar 3 dan 4), bahwa provinsi yang memiliki persentase pengguna internet rendah akan cenderung memiliki persentase pembeli online rendah, dan sebaliknya.
Hasil di atas juga sesuai dengan hasil penelitian-penelitian sebelumnya. Menurut Bellman et. al. (1999), pembeli online merupakan orang yang sudah menggunakan internet selama bertahun-tahun dan terbiasa menghabiskan banyak waktunya di internet. Selain itu, kebiasaan menggunakan internet akan mengurangi biaya yang harus dikeluarkan dan dapat mengurangi risiko pembelian online, sehingga kecenderungannya untuk berbelanja secara online akan meningkat.

Secara tidak langsung pendapatan perkapita memengaruhi persentase pembeli online melalui variabel persentase pengguna internet. Pendapatan perkapita akan meningkatkan persentase pengguna internet, dan persentase pengguna internet akan meningkatkan persentase pembeli online. Efek total dari variabel ini sebesar 0,580. Dampak langsung pendapatan perkapita terhadap persentase pembeli online tidak signifikan karena seseorang dengan pendapatan tinggi tidak selalu memiliki akses untuk melakukan pembelian secara online. Hal ini sesuai dengan pernyataan Mahmood et. al. (2004) bahwa terjadinya ketertinggalan dalam 
hal teknologi bukan hanya masalah pilihan pada individunya, melainkan juga menyangkut ketersediaan infrastruktur di daerahnya. Meskipun pendapatan seseorang tinggi, bukan berarti dia memiliki akses teknologi informasi yang baik. Hal ini sekaligus menjelaskan timbulnya dampak tidak langsung melalui persentase pengguna internet.

Hasil di atas dapat berlaku secara umum. Menurut Hawk (2004), salah satu penyebab kurang berkembangnya business to consumer (B2C) di suatu negara adalah rendahnya pendapatan perkapita negara tersebut. Pelaksanaan e-commerce bergantung pada infrastruktur telekomunikasi yang membutuhkan biaya investasi yang tidak sedikit, sehingga negara yang keadaan ekonominya kurang baik, tidak dapat terlibat dalam e-commerce dengan baik (Kurnia, 2006).

Rata-rata lama sekolah tidak memiliki dampak langsung terhadap persentase pembeli online. Namun variabel ini memiliki dampak tidak langsung terhadap persentase pembeli online melalui pendapatan perkapita dan persentase pengguna internet. Berdasarkan Tabel 6 dapat dilihat bahwa rata-rata lama sekolah mempunyai dampak langsung terhadap pendapatan perkapita, yaitu sebesar 0,626. Dampak total rata-rata lama sekolah terhadap persentase pengguna internet adalah sebesar 0,711 yang terdiri dari dampak langsung sebesar 0,311 dan dampak tidak langsung melalui pendapatan perkapita sebesar 0,400 . Hal ini sesuai dengan penelitian Chinn \& Fairlie (2007) serta Billon et. al. (2009). Sedangkan dampak total ratarata lama sekolah terhadap persentase pembeli online adalah sebesar 0,645. Hasil penemuan ini sesuai dengan hasil penelitian Bellman et. al. (1999), Brashear (2008), dan Kim et. al. (2012) yang menyatakan bahwa orang yang melakukan pembelian online memiliki tingkat pendidikan yang relatif lebih tinggi daripada yang tidak melakukan pembelian secara online. Dari hasil tersebut dapat disimpulkan bahwa jika rata-rata lama sekolah meningkat, persentase pengguna internet meningkat. Akibatnya, persentase pembeli online akan meningkat.

\section{KESIMPULAN DAN REKOMENDASI KEBIJAKAN}

Secara umum, persentase pembeli online di Indonesia masih rendah. Selain itu, persentase pembeli online antar provinsi di Indonesia berbeda signifikan. Persentase pengguna internet, rata-rata 
lama sekolah, dan pendapatan perkapita mempunyai pengaruh yang positif terhadap persentase pembeli online. Variabel yang dominan memengaruhi persentase pembeli online adalah persentase pengguna internet, sedangkan rata-rata lama sekolah dan pendapatan perkapita hanya memiliki pengaruh tidak langsung. Pendapatan perkapita memengaruhi persentase pembeli online melalui variabel persentase pengguna internet. Sementara variabel rata-rata lama sekolah memengaruhi persentase pembeli online melalui variabel persentase pengguna internet dan pendapatan perkapita.

Untuk meningkatkan bisnis jual/beli online, pemerintah bisa meningkatkan akses internet di Indonesia, mengingat variabel tersebut merupakan variabel yang paling besar pengaruhnya terhadap persentase pembeli online. Salah satu cara untuk meningkatkan akses internet di Indonesia adalah dengan meningkatkan infrastruktur komunikasi terutama di provinsi-provinsi di Indonesia bagian timur, misalnya membuat jalur fiber optik. Selain meningkatkan akses internet, pemerintah perlu meningkatkan pendidikan masyarakat karena masyarakat yang pendidikannya tinggi akan cenderung dapat lebih cepat beradaptasi dengan teknologi. Kebijakan-kebijakan terkait e-commerce akan efektif jika antar kementerian bekerja sama dan terintegrasi, terutama Kementerian Komunikasi dan Informatika, Kementerian Perdagangan, serta Kementerian Pendidikan dan Kebudayaan.

\section{UCAPAN TERIMA KASIH}

Puji syukur kepada Tuhan Yang Maha Esa, berkat rahmat dan hidayah Nya, penulis dapat menyelesaikan jurnal yang berjudul "Faktor-Faktor yang Memengaruhi Pembeli Online di Indonesia". Ucapan terima kasih juga penulis sampaikan kepada kedua orang tua dan seluruh keluarga yang telah membantu baik secara moril maupun materiil, serta seluruh pihak yang terlibat dalam penyusunan jurnal ini.

\section{DAFTAR PUSTAKA}

A'liyah, H. (2017). Analisis Tingkat Pengembalian Investasi Pendidikan Tenaga Kerja di Indonesia Tahun 2015. Jurnal Pendidikan dan Ekonomi, 6(3), 223-233.

Akhter, S. H. (2015). Impact of internet usage comfort and internet technical comfort on online shopping and online banking. Journal of International Consumer Marketing, 27(3), 207-219. 
Badan Pusat Statistik. (2016). Statistik Telekomunikasi Indonesia 2015. Jakarta: BPS.

Badan Pusat Statistik. (2018). Tabel Ratarata Lama Sekolah (Metode Baru). Diperoleh 16 Januari 2018, dari https://ipm.bps.go.id/data/nasional

Balabanis, G., Vassileiou, S. (1999). Some Attitudinal Predictors of HomeShopping Through the Internet. Journal of Marketing Management, Vol. 15 (5), pp. 361-385.

Bellman, A., Lohse, G .L., Johnson, E. J. (1999). Predictors of Online Buying Behavior. Communication of the $A C M$, Vol. 42 (12), pp. 32-38.

Bentler, P. M., Bonett, D.G. (1980). Significance Tests and Goodness of Fit in the Analysis of Covariance Structures. Psychological Bulletin, Vol. 88 (3), pp. 588-606.

Billon, M., Marco, R., Lera-Lopez, F. (2009). Disparities in ICT Adoption: A Multidimensional Approach to Study the Cross-Country Digital Divide. Telecommunications Policy, Vol. 33 (10-11), pp. 596-610.

Brashear, T. G. (2008). A Six-Country Comparison of The Internet Shopper Profile. Revista de Ciências da Administração, Vol. 10 (21), pp. 54-75.

Chinn, M. D., Fairlie, R. W. (2007). The Determinants of the Global Digital Divide: A Cross-Country Analysis of Computer and Internet Penetration. Oxford Economic Papers, Vol. 59 (1), pp. 16-44.

Dillon, W. R., Goldstein, M. (1984). Multivariate Analysis: Methods and Applications. New York: John Wiley \& Sons.

Dumičić, K., Bonić, I. S., \& Žmuk, B. (2018).
Statistical analysis of the development indicators' impacts on e-commerce of individuals in selected European countries. Naše gospodarstvo/Our economy, 64(2), 15-24.

Dumičić, K., Čeh Časni, A., \& Palić, I. (2014). Internet Purchases in European Union Countries: Multiple Linear Regression Approach. World Academy of Science, Engineering and Technology: International Journal of Social, Human Science and Engineering, 8(3), 193-199.

Elseoud, M. S. A. (2014). Electronic Commerce and Economic Growth in Saudi Arabia. International Journal of Economics, Commerce and Management, Vol. 5 (12).

Georgiou, M. N. (2009). E-Commerce Has A Positive Impact on Economic Growth: A Panel Data Analysis for Western Europe. Diunduh pada Tanggal $21 \mathrm{Mei}$ 2018 dari https://papers.ssrn.com/sol3/papers.cf m?abstract_id $=1484687$

Hawk, S. (2004). A Comparison of B2C ECommerce in Developing Countries. Electronic Commerce Research, Vol. 4 (3), pp. 181-199.

Kim, C., Galliers, R. D., Shin, N., Ryoo, J. H., Kim, J. (2012). Factors Influencing Internet Shopping Value and Customer Repurchase Intention. Electronic Commerce Research and Applications, Vol. 11 (4), pp. 374-387.

Kurnia, S. (2006). E-commerce Adoption in Developing Countries: an Indonesian Study. Makalah: Disajikan pada International Systems Conference pada Juli 2006 di San Diego.

Lawrence, J. E., Tar, U. A. (2010). Barriers to Ecommerce in Developing 
Countries. Information, Society and Justice, Vol. 3(1), pp. 23-35.

Liu, S. (2013). An Empirical Study on ECommerce's Effects on Economic Growth. Makalah: Disajikan pada International Conference on Education Technology and Management Science (ICETMS 2013).

Mahmood, M. A., Bagchi, K., Ford, T. C. (2004). On-line Shopping Behavior: Cross-Country Empirical Research. International Journal of Electronic Commerce, Vol. 9 (1), pp. 9-30.

Moorthy, S., Ratchford, B. T., Talukdar, D. (1997). Consumer Information Search Revisited: Theory and Empirical Analysis. Journal of Consumer Research, Vol. 23 (4), pp. 263-277.

Park, S. R., Choi, D. Y., \& Hong, P. (2015). Club convergence and factors of digital divide across countries. Technological Forecasting and Social Change, 96, 92-100.

Pasaribu, R, B, F., Kowanda, D., Firdaus M. (2017). Determinan Adopsi Ecommerce oleh Usaha Kecil Menengah. Jurnal Ekonomi \& Bisnis, Vol. 11 (2), pp. 63-87.
Pindyk, R. S., Rubinfeld, D. L. (2007). Mikroekonomi, Edisi Keenam (Jilid 1). Jakarta: PT Indeks.

Purnastuti, L., Miller, P., Salim, R. (2011). Economic Returns to Schooling in A Less Developed Country: Evidence for Indonesia. Makalah: Disajikan pada International Conference on Applied Economics pada Tahun 2011 di Department of Economics and Food Sciences, University of Perugia, Italy.

Ramzy, O., Eldahan, O. H. (2016). An Empirical Investigation of E-commerce in Egypt: The Impact of Culture on Online Purchasing. Global Business Review, Vol. 17 (5), pp. 1011-1025.

Sorce, P., Perotti, V., Widrick, S. (2005). Attitude and Age Differences in Online Buying. International Journal of Retail \& Distribution Management, Vol. 33 (2), pp. 122-132.

Stigler, G. J. (1961). The Economics of Information. Journal of Political Economy, Vol. 69 (3), pp. 213-225.

Taufiqurahman, E. (2018). Pengaruh Pendidikan dan Pengalaman pada Pendapatan Rumah Tangga di Indonesia. EKUITAS (Jurnal Ekonomi dan Keuangan), 17(4), 451-467. 
